\title{
Analyses of Bright and Burley Tobacco Laminae and Stems*
}

\author{
by Gordon H. Bokelman and William S. Ryan, Jr. \\ Philip Morris Research Center, Ricbmond, Virginia, U.S.A.
}

\section{SUMMARY}

One sample each of aged uncased, cured Bright lamina, Bright stems, Burley lamina and Burley stems were examined by a variety of general analytical methods and then characterized by our standard fractionation procedure. These tobacco samples were chosen to be reasonably representative of the tobaccos used in current commercial cigarette products. Although for a given variety of tobacco the concentrations of chemical constituents may vary as a function of stalk position, cultural management, geographic origin or crop year, we believe that the following conclusions based on these samples are generally valid: [1] levels of ethanol solubles, total reducing sugars and starch are much higher in Bright than in Burley, [2] concentrations of soluble ammoniz and nitrate are greater in Burley than in Bright, [3] total alkaloid and protein concentrations are higher in lamina than in stems, [4] cellulose, potassium and chloride concentrations are much greater in stems than in lamina, [5] concentrations of pectin, lignin and soluble hemicellulose do not vary greatly from one type of tobacco to another, [6] Burley lamina has greater concentrations of protein and acid detergent solubles than do the other types of tobaccos, and [7] Bright lamina has a much lower level of total ash than do the other types of tobaccos.

An examination of some of the components in ash led to the following conclusions: [1] total ash values are reasonable relative indicators of the level of non-nitrate inorganics, [2] a good estimate of the total contents of potassium, calcium, chloride, sulfate, phosphorus, silicon and magnesium may be obtained by multiplying the total ash value by 0.612 , and [3] it is likely that most of the potassium and calcium in total ash is actually present as carbonates rather than oxides.

The significantly higher levels of both protein and acid detergent solubles found in Burley lamina are thought to indicate that this protein may be unique in terms of its carbohydrate content or in terms of the nature or extent of its cross linkage.

\footnotetext{
- Presented at the 37th Tobacco Chemists' Research Conference, Arlington, Virginis, U.S.A, in 1983.

Received: 26th August 1983 - wcepted: 26th September 1984.
}

\section{ZUSAMMENFASSUNG}

Jeweils eine Probe abgelagerten und ungesoßten, getrockneten Rippen- bzw. Blattgutes von Virginia- und Burley-Tabak wurde unter Einsatz verschiedener herkömmlicher Analysemethoden auf ihre chemische $\mathrm{Zu}$ sammensetzung untersucht und dann mittels einer kürzlich von den Autoren entwickelten, standardisierten Fraktionierungsmethode charakterisiert. Die Proben wurden so ausgewählt, daß sie als hinreichend reprāsentativ für die gegenwärtig in der handelsüblichen Zigarettenproduktion verwendeten Tabake anzusehen sind. Wenn die Mengen der in einer Tabaksorte enthaltenen chemischen Bestandteile auch je nach der Position der Blätter an der Sproßachse, den landwirtschaftlichen Anbaumethoden, der geographischen Provenienz und den Witterungsbedingungen des jeweiligen Erntejahres schwanken können, wird den im folgenden dargelegten Untersuchungsergebnissen von den Autoren doch allgemeine Gültigkeit beigemessen: [1] VirginiaTabak enthält viel mehr in Ethanol lösliche Verbindungen, gesamte reduzierende Zucker und Stärke als Burley-Tabak. [2] Der Gehalt an löslichem Ammoniak und Nitrat ist in Burley-Tabak höher als in Virginia-Tabak. [3] Die Konzentration an Gesamtalkaloiden und Protein ist im Blattgewebe höher als in den Rippen. [4] Cellulose, Kalium und Chlorid sind in den Rippen in viel höheren Konzentrationen vertreten als im Blattgewebe. [5] Die verschiedenen Proben unterscheiden sich in ihrem Gehalt an Pektin, Lignin und löslicher Hemicellulose nicht wesentlich voneinander. [6] Das Blattgewebe von Burley-Tabak enthält mehr Protein und mehr in sauren Detergenzien lösliche Substanzen als die anderen Proben. [7] Das Blattgewebe des Virginia-Tabaks ergibt viel weniger Gesamtasche als die anderen Proben.

Einige der genannten Verbindungen wurden in der Asche mit folgenden Ergebnissen untersucht: [1] Die Gesamtausbeute an Asche ist ein Maß für den Gehalt an anorganischen Inhaltsstoffen außer Nitrat. [2] Durch Multiplikation des Wertes der Menge der Gesamtasche mit 0,612 kann der Gehalt insgesamt an Kalium, Calcium, Chlorid, Sulfat, Phosphor, Silicium und Magnesium gut abgeschătzt werden. [3] Wahrscheinlich liegt das meiste in der Gesamtasche befindliche Kalium und Calcium eher als Carbonat denn als Oxid vor. 
Der signifikant höhere Gehalt des Blattgewebes von Burley-Tabak sowohl an Protein wie auch an in sauren Detergenzien löslichen Substanzen deutet nach Meinung der Autoren darauf hin, daß dieses Protein bezüglich der Menge der in ihm enthaltenen Kohlehydrate und auch bezüglich der Art und des Ausmaßes seiner Quervernetzungen einzigartig sein kōnnte.

\section{RÉSUME}

Sur du tabac Burley et du tabac de Virginie après maturation en stock, on préleva respectivement un échantillon de côtes et de parenchyme, non saucé et $\mathrm{sec}$, afin d'en déterminer la composition chimique par différentes méthodes traditionnelles d'analyse. Les échantillons, qui avaient été choisis de manière à pouvoir être considérés comme suffisamment représentatifs des tabacs utilisés actuellement pour la production des cigarettes vendues dans le commerce, furent ensuite caractérisés au moyen d'un procédé de fractionnement standardisé récemment mis au point par les auteurs de l'étude. Si les concentrations des différents composés chimiques contenus dans une variété de tabac donnée peuvent dépendre de la position des feuilles sur la tige, des méthodes de culture employées, de la provenance géographique et des conditions météorologiques pendant l'année de la récolte, les conclusions présentées dans les lignes suivantes n'en ont pas: moins une valeur générale: [1] Le tabac de Virginie contient beaucoup plus de composés solubles dans l'éthanol, de sucres totaux réducteurs et d'amidon que le tabac Burley. [2] La teneur du tabac Burley en ammoniac soluble et nitrates est plus élevée que celle du tabac de Virginie. [3]. La concentration en alcaloīdes totaux et protéines est plus grande dans le tissu foliaire que dans les côtes. [4] Cellulose, potassium et chlorures sont présents à une concentration beaucoup plus forte dans les côtes que dans le tissu foliaire. [5] Les différents échantillons ne se distinguent pas essentiellement les uns des autres par leur teneur respective en pectine, lignine et hémicellulose soluble. [6] Le tissu foliaire du tabac Burley contient davantage de protéine et de substances solubles dans les détergents acides que les autres échantillons. [7] Le tissu foliaire du tabac de Virginie donne beaucoup moins de cendres totales que les autres échantillons.

L'examen de quelques-uns des composés des cendres a conduit aux conclusions suivantes: [1] Le rendement en cendres totales est un indicateur de la teneur en substances non organiques, exception faite des nitrates. [2] Une bonne estimation de la teneur totale en potassium, calcium, chlorure, sulfate, phosphore, silicium et magnésium peut être obtenue en multipliant par 0,612 le nombre donnant la quantité de cendre totale. [3] Il est probable que la majeure partie du potassium et du calcium présents dans les cendres se trouve sous forme de carbonate plutôt que d'oxyde.

De l'avis des auteurs, la teneur nettement plus élevée du tissu foliaire du tabac Burley tant en protéine qu'en substances solubles dans les détergents acides, semble indiquer que cette protéine est unique en son genre en ce qui concerne les hydrates de carbone qu'elle contient ainsi que la nature et l'étendue de sa structure réticulaire transversale.

\section{INTRODUCTION}

Several comprehensive reviews on the constituents of tobacco are available $(1-5)$. In general the literature has been more concerned with low molecular weight components than with polymeric cell wall constituents.

This present research was undertaken to determine the biopolymer cell wall compositions of one representative sample each of cured Bright lamina, Bright stems, Burley lamina and Burley stems using a new fractionation procedure (6). The starting tobacco materials were also thoroughly analyzed by a number of conventional procedures. The results of these analyses were used to establish a relationship between total ash and inorganic components.

\section{EXPERIMENTAL}

One sample each of the following aged uncased, cured tobaccos were used in this study: Bright lamina, Bright stems, Burley lamina and Burley stems. The Bright lamin a came from a single grade of heavy, or bodied, fluecured Bright tobacco harvested at the upper mid-stalk position. The Burley lamina was a blend which was representative of the Burley used in current commercial cigarette products. The Bright and Burley stem samples were each representative of stems obtained from the lower one-third stalk positions of their respective tobacco types for a typical crop year. All the tobacco samples were ground to pass a 20 mesh screen.

The samples were analyzed by a number of conventional procedures. A combined automated colorimetric procedure was used for the determination of total reducing sugars and total alkaloids (7). The reducing sugar procedure was based on the reaction of reducing sugars with $p$-hydroxybenzoic acid hydrazide. The determination of total alkaloids utilized the reaction of nicotine alkaloids with cyanogen chloride. Total nitrogen was determined by a Kjeldahl procedure (8). The analysis for nitrate nitrogen utilized a hydrazine reduction procedure followed by diazotization (9). The determination of soluble ammonia was based on the reaction of ammonia, sodium salicylate and sodium hypochlorite in an alkaline medium (10). Citric, malic and oxalic acids were quantitated by gas chromatography following conversion to their respective methyl esters (11). Chlorogenic acid and rutin were determined by high-performance reverse-phase liquid chromatography (12). Total ash was determined gravimetrically following combustion of tobacco samples at $550^{\circ} \mathrm{C}$. The analyses for potassium, calcium and magnesium utilized atomic absorption spectrophotometry (13). Chloride 
was determined by potentiometric titration with silver nitrate (14). Sulfate was determined turbidimetrically on an acid extract of the ashed sample after the addition of barium chloride (15). The determination of phosphorus was based on the colorimetric molybdovanadate reaction (16). Silicon was determined by an atomic absorption procedure after dissolution in hydrofluoric acid (17).

The biopolymer cell wall compositions of these tobacco samples were determined by a slightly modified version of our standard fractionation procedure (6) shown in Figure 1. In this paper a single analysis for Klason lignin (27) was performed on the residue from treatment with Termamyl ${ }^{\bullet}$ 60-L enzyme (Novo Laboratories, Inc.). As usual, the Klason residue was corrected for protein and ash contents.

\section{RESULTS AND DISCUSSION}

\section{General Analyses and \\ an Examination of Total Ash}

Table 1 lists the values for the general analyses which were performed on the four tobacco samples. A number of well-known trends are evident from these data. Bright tobacco has high levels of total reducing sugars, while Burley does not. Burley tobacco has higher levels of soluble ammonia and total nitrogen than does Bright tobacco. Burley stems have a much greater concentration of nitrate than do the other types of tobacco. Po-

Table 1.

General analyses of Bright and Burley laminae and stems (all values expressed on a percentage dry weight basis).

\begin{tabular}{l|c|c|c|c}
\hline \multicolumn{1}{c|}{ Analysis } & $\begin{array}{c}\text { Bright } \\
\text { lamina }\end{array}$ & $\begin{array}{c}\text { Bright } \\
\text { stems }\end{array}$ & $\begin{array}{c}\text { Burley } \\
\text { lamina }\end{array}$ & $\begin{array}{c}\text { Burley } \\
\text { stems }\end{array}$ \\
\hline Total & & & & \\
reducing sugars & 12.9 & 6.5 & n.d. & n.d. \\
Total alkaloids & 3.76 & 0.85 & 3.16 & 0.95 \\
Total nitrogen & 2.83 & 1.96 & 4.36 & 3.22 \\
Nitrate nitrogen & $<0.04$ & 0.50 & 0.54 & 2.51 \\
Soluble ammonia & $<0.1$ & $<0.1$ & 0.51 & 0.36 \\
Citric acid & 0.7 & 0.5 & 5.3 & 0.9 \\
Malic acid & 3.7 & 7.8 & 4.8 & 3.0 \\
Oxalic acid & 1.3 & 1.4 & 2.9 & 1.9 \\
Chlorogenic acid & 1.47 & 0.14 & n.d. & n.d. \\
Rutin & 0.74 & 0.04 & 0.05 & n.d. \\
Total ash & 10.2 & 20.4 & 21.0 & 26.2 \\
Potassium & 2.3 & 7.2 & 4.0 & 9.1 \\
Calcium & 1.5 & 1.8 & 4.0 & 3.3 \\
Chloride & 0.46 & 1.88 & 0.58 & 1.47 \\
Sulfate & 1.1 & 1.1 & 1.9 & 1.4 \\
Phosphorus & 0.40 & 0.31 & 0.25 & 0.29 \\
Silicon & 0.19 & 0.13 & 0.63 & $<0.10$ \\
Magnesium & 0.40 & 0.53 & 0.64 & 0.56 \\
\hline
\end{tabular}

tassium and chloride concentrations are much greater in stems than in lamina. But the level of total alkaloids is much higher in lamina than in stems.

Certain facts which are apparent from Table 1 may be less well known. The greatest concentration $(7.8 \%)$ of malic acid is found in Bright stems. However, Burley lamina has a much greater concentration of citric acid than do the other tobacco samples. Burley lamina also has greater concentrations of calcium and oxalic acid than do the other types of tobaccos. In fact, Burley lamina is the only tobacco sample which does not contain considerably more potassium than calcium. Bright lamina is noteworthy for having a much lower level of total ash than do the other types of tobacco.

Due to the large differences which exist in total ash values between Bright lamina and all of the other tobacco samples, attempts were made to gain a better understanding of what total ash really means.

Our analytical procedure for total ash utilized a gravimetric determination following ignition of tobacco samples at $550^{\circ} \mathrm{C}$. It was assumed that during combustion the organic materials are burned and the inorganic materials such as calcium, potassium and magnesium salts, inorganic phosphates, chlorides, and sulfates, and silica remain as ash. However, it may be seen in Table 2 that for all the tobacco samples a summation of the values for potassium, calcium, chloride, sulfate, phosphorus, silicon and magnesium is considerably less than the total ash value. This led us to consider whether part of the difference might be attributable to nitrate.

Analysis for nitrate by an experimental ion chromatographic procedure revealed no measurable quantity of nitrate in the ash from the Burley stem sample (18).

Table 2.

Comparison of the concentrations of inorganlc components and total ash (all values expressed on a percentage dry weight basis).

\begin{tabular}{lc|c|c|c}
\cline { 2 - 5 } & $\begin{array}{c}\text { Bright } \\
\text { lamina }\end{array}$ & $\begin{array}{c}\text { Bright } \\
\text { stems }\end{array}$ & $\begin{array}{c}\text { Burley } \\
\text { lamina }\end{array}$ & $\begin{array}{c}\text { Burley } \\
\text { stems }\end{array}$ \\
\hline Total ash & 10.2 & 20.4 & 21.0 & 26.2 \\
Potassium & 2.3 & 7.2 & 4.0 & 9.1 \\
Calcium & 1.5 & 1.8 & 4.0 & 3.3 \\
Chloride & 0.5 & 1.9 & 0.6 & 1.5 \\
Sulfate & 1.1 & 1.1 & 1.9 & 1.4 \\
Phosphorus & 0.4 & 0.3 & 0.3 & 0.3 \\
Sillicon & 0.2 & 0.1 & 0.6 & trace \\
Magnesium & 0.4 & 0.5 & 0.6 & 0.6 \\
\hline
\end{tabular}

Sum of the above

non-nitrate

inorganics

$\begin{array}{lll}6.4 & 12.9 & 12.0\end{array}$

16.2

Nitrate ( $=$ nitrate nitrogen $\times$ 4.43)

$\begin{array}{llll}\text { trace } & 2.2 & 2.4 & 11.1\end{array}$

Sum of all

inorganics

6.4

$15.1 \quad 14.4$

27.3

Sum of non-nitrate

inorganics /

total ash

0.627 
Table 3.

Comparison of the concentrations of inorganic components (calculated as their oxides) and total ash (all values expressed on a percentage dry weight basis).

\begin{tabular}{|c|c|c|c|c|}
\hline & $\begin{array}{l}\text { Bright } \\
\text { lamina }\end{array}$ & $\begin{array}{l}\text { Bright } \\
\text { stems }\end{array}$ & $\begin{array}{l}\text { Burley } \\
\text { lamina }\end{array}$ & $\begin{array}{l}\text { Burley } \\
\text { sterns }\end{array}$ \\
\hline Total ash & 10.2 & 20.4 & 21.0 & 26.2 \\
\hline Potassium as $\mathrm{K}_{2} \mathrm{O}$ & 2.8 & 8.6 & 4.8 & 10.9 \\
\hline Calcium as $\mathrm{CaO}$ & 2.1 & 2.5 & 5.6 & 4.6 \\
\hline Chloride & 0.5 & 1.9 & 0.6 & 1.5 \\
\hline Sulfate & 1.1 & 1.1 & 1.9 & 1.4 \\
\hline $\begin{array}{l}\text { Phosphorus as } \\
\mathrm{P}_{2} \mathrm{O}_{5}\end{array}$ & 0.9 & 0.7 & 0.6 & 0.7 \\
\hline Sillicon as $\mathrm{SiO}_{2}$ & 0.4 & 0.3 & 1.3 & trace \\
\hline $\begin{array}{l}\text { Magnesium as } \\
\text { MgO }\end{array}$ & 0.7 & 0.9 & 1.1 & 0.9 \\
\hline Sum of the above & 8.5 & 16.0 & 15.9 & 20.0 \\
\hline $\begin{array}{l}\text { Sum of the above / } \\
\text { total ash }\end{array}$ & 0.833 & 0.784 & 0.757 & 0.763 \\
\hline
\end{tabular}

This finding is consistent with the Chemical Rubber Co. (CRC) Handbook of Chemistry and Physics which reports that potassium nitrate decomposes at $400^{\circ} \mathrm{C}$. If the nitrate in tobacco completely decomposes to nitrogen oxides and oxygen, it should not contribute to the total ash residue.

It is interesting to note in Table 2 that the ratio of nonnitrate inorganics to total ash for all four tobacco samples varies over only a relatively small range even though the values for potassium, nitrate, calcium and chloride show large variations. For this set of tobacco samples the mean value for the ratio of non-nitrate inorganics to total ash is 0.612 with a relative standard deviation, at $\sigma=2$, of $\pm 7.9 \%$. In other words, for any of these diverse tobacco samples taking $61.2 \%$ of the total ash value gives a very good estimate of the total contents of potassium, calcium, chloride, sulfate, phosphorus, silicon and magnesium.

The question still remains of how to rationalize the difference in weights between total ash and non-nitrate inorganics. It has been assumed frequently that magne- sium, silicon, phosphorus, calcium and potassium are present in ash as their respective oxides (19). However, as shown in Table 3, there are still sizeable discrepancies between the total ash values and summations of the non-nitrate inorganics expressed as oxides.

In view of these discrepancies, it seems reasonable to suggest that the calcium may be present in the total ash predominantly as the carbonate rather than the oxide. It is known that calcium oxalate decomposes to calcium carbonate at $475-525^{\circ} \mathrm{C}(20)$, which is lower than the $550^{\circ} \mathrm{C}$ temperature used for the total ash procedure. It may be that other organic salts containing calcium, such as calcium pectate, may also form calcium carbonate during the total ash procedure. Once formed, calcium carbonate would be stable in this procedure since it does not decompose into calcium oxide and carbon dioxide until a temperature of $825^{\circ} \mathrm{C}$ is achieved (21). By analogous reasoning, if calcium and potassium salts behave in a similar manner during combustion, then the potassium also may be present in the total ash predominantly as the carbonate rather than the oxide.

To test these hypotheses the ash samples were analyzed for carbonate by a gas chromatographic procedure (22). This procedure actually determines carbon dioxide generated from carbonate upon acidification, which is expressed as percent of total ash. It may be seen in Table 4 that the carbonate content quantitatively accounts for the difference in weights between total ash and nonnitrate inorganics expressed as oxides. Thus it is likely that most of the potassium and calcium in total ash is actually present as carbonates rather than oxides.

Of course many trace elements are also found in total ash but collectively they represent less than $0.02 \%$ of the dry weight of tobacco (23).

\section{Biopolymer Cell Wall Compositions}

The four ground, uncased tobaccos were separated into six fractions each by the scheme shown in Figure 1. The weight of solid material present in each fraction is reported in Table 5. A material balance for each tobacco was obtained by analysis of these fractions for selected tobacco components.

Table 4.

Comparieon of the concentrations of total ash, Inorganic components (calculated as their oxides) and carbonate (all values expressed on a percentage dry weight basis except as noted).

\begin{tabular}{lc|c|c|c}
\cline { 2 - 5 } & $\begin{array}{c}\text { Bright } \\
\text { lamina }\end{array}$ & $\begin{array}{c}\text { Bright } \\
\text { stems }\end{array}$ & $\begin{array}{c}\text { Burley } \\
\text { lamina }\end{array}$ & $\begin{array}{c}\text { Burley } \\
\text { stems }\end{array}$ \\
\hline $\begin{array}{l}\text { Total ash } \\
\begin{array}{l}\text { Sum of inorganic components } \\
\text { calculated as their oxides }\end{array}\end{array}$ & 10.2 & 20.4 & 21.0 & 26.2 \\
$\begin{array}{l}\text { (I) Sum of the above } \\
\text { expressed as percentage of total ash }\end{array}$ & 8.5 & 16.0 & 15.9 & 20.0 \\
$\begin{array}{l}\text { (II) } \mathrm{CO}_{2} \text { generated from carbonate } \\
\text { expressed as percentage of total ash }\end{array}$ & 83.3 & 78.4 & 75.7 & 76.3 \\
\hline I plus II & 16.2 & 20.6 & 23.9 & 25.0 \\
\hline
\end{tabular}

* see Table 3. 
Flgure 1.

Fractionation of tobacca for determination of cell wall components.

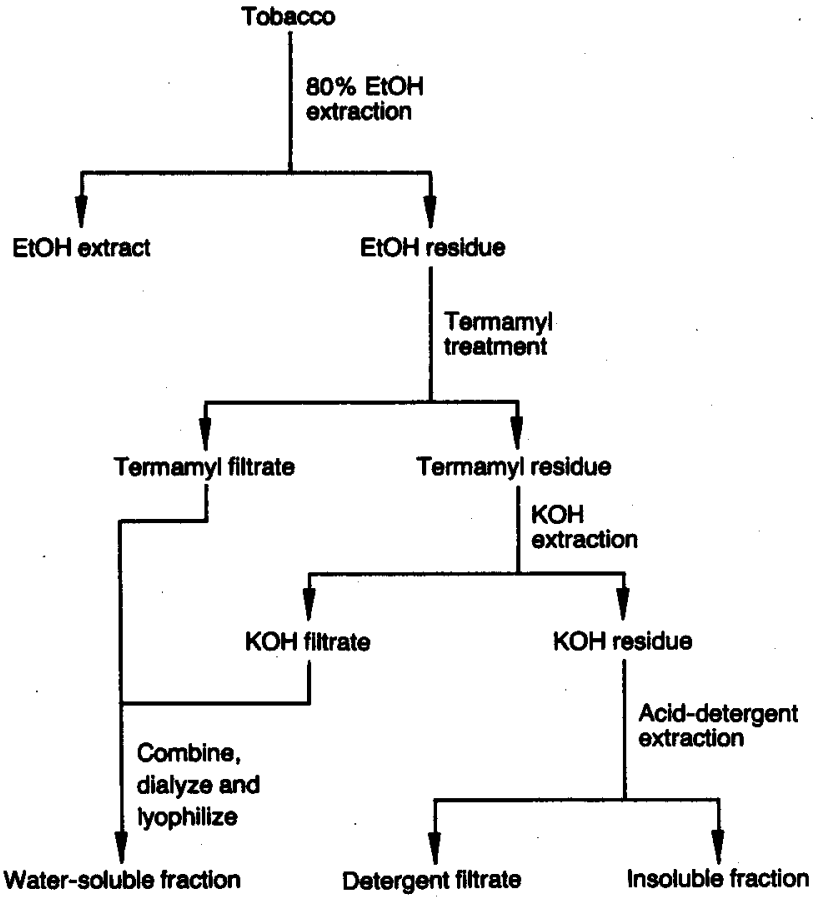

The starch content of the starting tobacco samples was determined by a glucose oxidase colorimetric method (24). The amount of pectin in the tobacco materials was calculated from the uronic acid content of the EtOH residue. The protein content was obtained by multiplying the total nitrogen values of the Termamyl residues by the conventional factor 6.25 . The Termamyl resi-
Table 5.

Fractlon welghts (expressed as percentage of starting material on a dry weight basis).

\begin{tabular}{l|c|c|c|c}
\hline \multicolumn{1}{c|}{ Fraction } & $\begin{array}{c}\text { Bright } \\
\text { lamina }\end{array}$ & $\begin{array}{c}\text { Bright } \\
\text { stems }\end{array}$ & $\begin{array}{c}\text { Burley } \\
\text { lamina }\end{array}$ & $\begin{array}{c}\text { Burley } \\
\text { stems }\end{array}$ \\
\hline Starting material & 100 & 100 & 100 & 100 \\
EtOH extract & 56.3 & 41.6 & 31.5 & 31.0 \\
EtOH residue & 45.9 & 59.7 & 67.7 & 68.2 \\
Termamyl residue & 28.2 & 42.5 & 46.8 & 53.4 \\
KOH residue & 12.2 & 22.2 & 20.0 & 28.6 \\
Water-soluble & & & & \\
fraction & 15.4 & 15.4 & 14.8 & 12.3 \\
Insoluble fraction & 8.5 & 17.6 & 10.0 & 21.8 \\
\hline
\end{tabular}

dues, water-soluble fractions, and insoluble fractions from each of the tobaccos were analyzed by the neutral sugar procedure of Ryan (25). These results are summarized in Tables 6 and 7. The lignin content of the samples was calculated from the Klason residue values for the Termamyl residues. The hemicellulose and cellulose values were calculated from the neutral sugar content of the water-soluble and insoluble fractions. A more detailed discussion of the methodology used to calculate these values has been reported previously (6).

The biopolymer cell wall compositions determined for the four tobacco samples are summarized in Table 8. Several trends are apparent. The levels of ethanol solubles are higher in Bright tobacco than in Burley. The extraction with aqueous ethanol removes low molecular weight compounds. The ethanol solubles are thought to include reducing sugars, organic acids, alkaloids, polyphenols, lipids, waxes, resins, some pigments and a

Table 8.

Blopolymer cell wall compositions of Bright and Burley laminae and stems (all values expressed on a percentage dry weight basis).

\begin{tabular}{|c|c|c|c|c|}
\hline Tobacco component & $\begin{array}{l}\text { Bright } \\
\text { lamina }\end{array}$ & $\begin{array}{l}\text { Bright } \\
\text { stems }\end{array}$ & $\begin{array}{l}\text { Burley } \\
\text { lamina }\end{array}$ & $\begin{array}{l}\text { Burley } \\
\text { stems }\end{array}$ \\
\hline Ethanol solubles & 56.3 & 41.6 & 31.5 & 31.0 \\
\hline $\begin{array}{l}\text { Aqueous solubles lost } \\
\text { during dialysis }\end{array}$ & 5.2 & 13.5 & 19.5 & 14.6 \\
\hline Acld detergent solubles & 3.2 & 4.3 & 8.8 & 6.2 \\
\hline Pectin & 10.7 & 12.4 & 11.5 & 14.8 \\
\hline Starch & 3.2 & 0.4 & trace & trace \\
\hline Protein & 6.8 & 3.4 & 10.4 & 4.1 \\
\hline $\begin{array}{l}\text { Hemicellulose: } \\
\text { soluble } \\
\text { associated with cellulose }\end{array}$ & $\begin{array}{l}2.8 \\
0.8\end{array}$ & $\begin{array}{l}3.2 \\
1.8\end{array}$ & $\begin{array}{l}2.3 \\
0.9\end{array}$ & $\begin{array}{l}2.5 \\
2.4\end{array}$ \\
\hline Lignin & 1.7 & 2.2 & 2.1 & 2.4 \\
\hline Cellulose & 5.9 & 11.7 & 6.4 & 15.4 \\
\hline $\begin{array}{l}\text { Ash: } \\
\text { soluble } \\
\text { insoluble }\end{array}$ & $\begin{array}{l}2.8 \\
1.0\end{array}$ & $\begin{array}{l}1.3 \\
0.2\end{array}$ & $\begin{array}{l}1.2 \\
0.6\end{array}$ & $\begin{array}{r}1.4 \\
\operatorname{trace}\end{array}$ \\
\hline Total & 100.4 & 96.0 & 95.2 & 94.8 \\
\hline
\end{tabular}




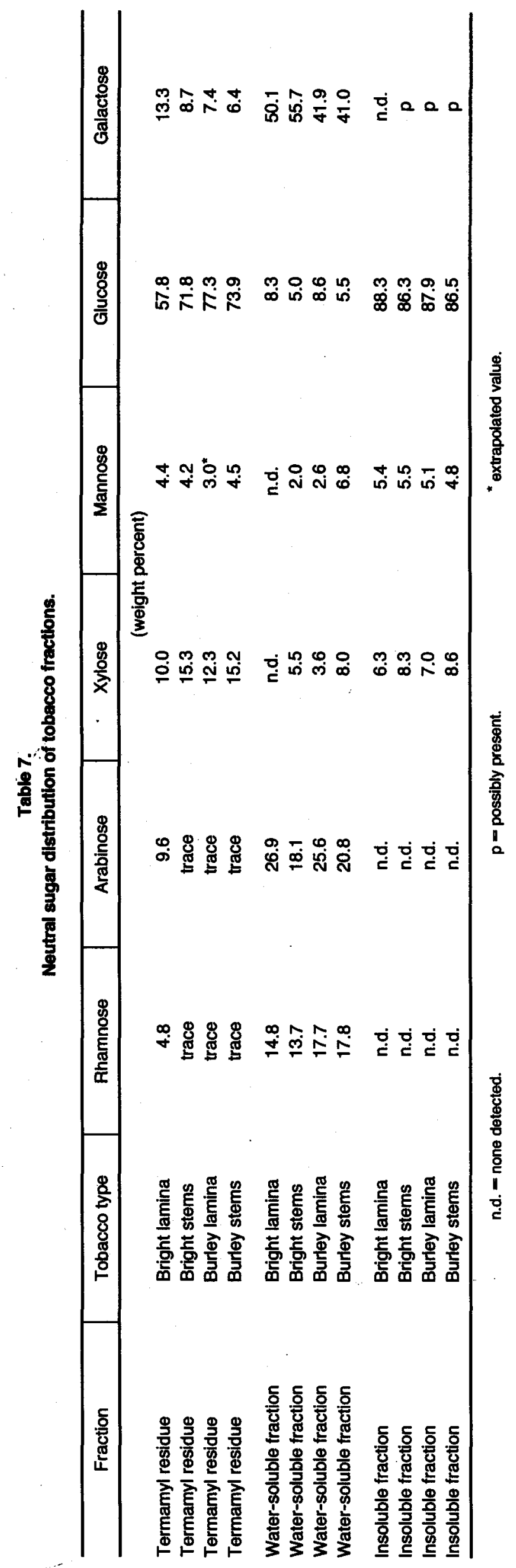


Table 6.

Neutral sugar analysis of tobacco fractions.

\begin{tabular}{|c|c|c|c|}
\hline Fraction & Tobacco type & $\begin{array}{c}\text { Neutral sugars } \\
(\%)\end{array}$ & $\begin{array}{c}\text { Klason residue } \\
(\%)\end{array}$ \\
\hline Termamyl residue & Bright lamina & 35.4 & 11.0 \\
\hline Termamyl residue & Bright stems & 15.8 & 9.2 \\
\hline Termamyl residue & Burley lamina & 8.9 & 9.2 \\
\hline Termamyl residue & Burley stems & 16.5 & 7.5 \\
\hline Water-soluble fraction & Bright lamina & 22.3 & 5.5 \\
\hline Water-soluble fraction & Bright stems & 26.3 & 7.9 \\
\hline Water-soluble fraction & Burley lamina & 18.7 & 8.6 \\
\hline Water-soluble fraction & Burley stems & 25.0 & 3.6 \\
\hline Insoluble fraction & Bright lamina & 87.8 & 20.0 \\
\hline Insoluble fraction & Bright stems & 85.0 & 9.0 \\
\hline Insoluble fraction & Burley lamina & 82.2 & 15.0 \\
\hline Insoluble fraction & Burley stems & 90.6 & 9.1 \\
\hline
\end{tabular}

portion of the water-soluble salts. The aqueous solubles lost during dialysis values represent those tobacco components with a molecular weight less than 12,000 that were soluble in either the neutral Termamyl or $0.1 \mathrm{M}$ $\mathrm{KOH}$ extraction solutions. The Termamyl treatment was employed to remove starch while the KOH extraction was designed to solubilize hemicellulose, protein and pectin. The data show that protein concentrations are greater in lamina than in stems. Burley lamina has significantly higher levels of both protein (26) and acid detergent solubles than do the other tobacco samples. These two facts may be related in that the protein found in Burley lamina may be unique in terms of its carbohydrate content or in terms of the nature or extent of its cross linkage.

It is interesting to note that the concentration of pectin, lignin and soluble hemicellulose do not vary greatly from one type of tobacco to another. Lignin content is less than 3 percent for all the tobacco samples. Thus even in Burley stems, which have the highest level of cellulose, the combined content of cellulose and lignin is less than 18 percent. Clearly tobacco stems are a herbaceous, rather than a wood-like, material.

The acid detergent extraction was designed to remove the hemicellulose and pectin not solubilized in the previous extractions and thus further purify the insoluble residue. The higher values for acid detergent solubles in Burley indicate that Burley tobacco has either more hemicellulose or different types of hemicellulosic components than does Bright.

The insoluble fraction contains xylose and mannose in addition to glucose. The presence of these two neutral sugars indicates that there is an insoluble hemicellulosic component in tobacco. The ratio of cellulose to hemicellulose associated with cellulose is a relatively constant value, approximately 6.7 to 1 for all four types of tobacco. Based on all our experience to date, we believe that this hemicellulosic fraction, which probably consists of xylans and mannans, is bound to the surface of the cellulose in such a manner that it would be difficult to remove without degradation of the cellulose.

\section{REFERENCES}

1. Tso, T. C.: Physiology and biochemistry of tobacco plants; Dowden, Hutchinson \& Ross, Inc., Stroudsburg, $\mathrm{Pa}$., 322-339, 1972.

2. Stedman, R. L.: The chemical composition of tobacco and tobacco smoke; Chem. Rev. 68 (1968) 153-207.

3. Wynder, E. L., and D. Hoffmann: Tobacco and tobacco smoke, Studies in experimental carcinogenesis; Academic Press, New York, N. Y., 317-501, 1967.

4. Johnstone, R. A. W., and J. R. Plimmer: The chemical constituents of tobacco and tobacco smoke; Chem. Rev. 59 (1959) 885-936.

5. Phillips, M., and A. M. Bacot: The chemical composition of certain grades of type 11, American flue-cured tobacco; J. Assoc. Off. Agric. Chem. 36 (1953) 504-524.

6. Bokelman, G. H., W. S. Ryan, Jr., and E. T. Oakley: Fractionation of Bright tobacco; J. Agric. Food Chem. 31 (1983) 897-901.

7. Davis, R. E.: A combined automated procedure for the determination of reducing sugars and nicotine alkaloids in tobacco products using a new reducing sugar method; Tob. Sci. 20 (1976) 146-151.

8. Gehrke, C. W., J. S. Killingley and L. L. Wall, Sr.: Missouri automated nitrogen method (MANM) for fertilizers; J. Assoc. Off. Anal. Chem. 55 (1972) 467-480.

9. Kamphake, L. J., S. A. Hannah and J. M. Cohen: Automated analysis for nitrate by hydrazine reduction; Water Res. 1 (1967) 205-216. 
10. Crooke, W. M., and W. E. Simpson: Determination of ammonium in Kjeldahl digests of crops by an automated procedure; J. Sci. Food Agric. 22 (1971) 9-10.

11. Harvey, W. R., R. W. Hale and R. M. Ikeda: The determination of organic acids in plants and food products; Tob. Sci. 14 (1970) 141--144.

12. Court, W. A.: High-performance reversed-phase liquid chromatography of naturally occurring phenolic compounds; J. Chromatogr. 130 (1977) 287291.

13. Isaac, R. A., and W. C. Johnson: Collaborative study of wet and dry techniques for the elemental analysis of plant tissue by atomic absorption spectrophotometry; J. Assoc. Off. Anal. Chem. 58 (1975) $436-440$.

14. Horwitz, W.: Official methods of analysis of the Association of Official Analytical Chemists (thirteenth edition); Association of Official Analytical Chemists, Washington, D. C., 1980, p. 51.

15. Harvey, W. R.: Manual determination of nitrate and sulfate in tobacco and tobacco products; Tob. Sci, 23 (1979) 25-28.

16. Gehrke, C. W., J. H. Baumgartner and J. P. Ussary: Automation of the AOAC photometric phosphomolybdovanadate method for direct available $\mathrm{P}_{2} \mathrm{O}_{5}$; J. Assoc. Off. Anal. Chem. 49 (1966) 12131218.

17. Sulcek, Z., P. Povondra and J. Dolezal: Decomposition procedures in inorganic analysis; Crit. Rev. Anal. Chem. 6 (1977) 255-323.

18. Harvey, W. R.: Unpublished research, 1983 (Philip Morris Research Center, Richmond, Virginia).

19. Tso, T. C.: Tobacco; in: Encyclopedia of chemical technology, second edition, Vol. 20, edited by $\mathrm{A}$. Standen, Interscience Publishers, New York, N. Y., 1969, p. 511.

20. Meites, L.: Handbook of analytical chemistry; McGraw-Hill Book Company, New York, N. Y., 1963 , p. 3-17.
21. The Merck Index, Ninth Edition; Merck \& Co., Inc., Rahway, N. J., 1976, p. 210.

22. Randolph, H. R.: Unpublished research, 1983 (Philip Morris Research Center, Richmond, Virginia).

23. Nadkarni, R. A., and W. D. Ehmann: Determination of trace elements in tobacco products by neutron activation analysis; in: Proceedings of the tobacco and health workshop, Conf. Rep. 1, University of Kentucky Tobacco and Health Research Institute, Lexington, Ky., 1969, pp. 47-57.

24. Oakley, E. T.: Enzymatic determination of starch in fresh green, lyophilized green, and cured tobacco; J. Agric. Food Chem. 31 (1983) 902-905.

25. Ryan, W. S., Jr.: Neutral sugar analysis of tobacco cell wall fractions; Beitr. Tabakforsch. Int. 12 (1984) 105-111.

26. Hamilton, J. L., and R. H. Lowe: Changes in the concentration of proteins, amino acids and ammonia in Burley tobacco during air curing; Tob. Sci. 22 (1978) 89-93.

27. Sarkanen, K. V., and C. H. Ludwig: Lignins - occurrence, formation, structure and reactions; Wiley-Interscience, New York, N.Y., 1971.

\section{Acknowledgements}

The technical assistance of Dr. H. Sun, Ms. E. Oakley, Mr. W. Suiter, Ms. B. Handy, Ms. C. Smiley, Ms. K. Mitchell and Mr. G. Baker is gratefully acknowledged.

\section{Authors' address:}

Pbilip Morris Research Center,

P. O. Box 26583,

Ricbmond, Virginia, 23261, U.S.A. 